International Journal of Psychological Research and Reviews
(ISSN:2639-6041)

\title{
Prevalence in the Use of Anxiolytics Among Nursing Professionals: an Integrative Review
}

Cléber José da Silva ${ }^{1 *}$, Rosana Maria da Conceição Silva ${ }^{1}$, Felipe Ravelly Alves de Souza ${ }^{1}$, Samanta Sabrina dos Santos Lopes ${ }^{2}$, Taciane Maria da Silva ${ }^{2}$, Rêneis Paulo Lima Silva ${ }^{2}$

${ }^{1}$ Universidade Federal de Pernambuco - Depto. de Antibióticos, Recife, PE, Brasil; ${ }^{2}$ Centro Universitário Estácio do Recife, Recife, PE, Brasil.

\section{ABSTRACT}

Introduction: Anxiety disorders have increased significantly in the last century, mainly due to the profound transformations that occurred in the economic and cultural context that were accompanied by the pressures of a modern, technological and mainly increasingly competitive society. Health professionals have a weakness and ease regarding the use of psychotropic drugs due to excessive stress, excessive workload, charges, dissatisfaction in the workplace or family. Objective: To identify prevalence of anxiolytic use by nursing professionals between 2013 and 2018. Methodology: Integrative review conducted in the LILACS, VHL and Pubmed databases, including quantitative research articles in Portuguese and English. Those whose methodological descriptions provided insufficient information were excluded. Results: The searches led to 400 articles which, after applying the inclusion and exclusion criteria, formed a corpus of 07 articles. The results indicate a high prevalence of anxiolytic use among health professionals for female nursing workers, married, with working hours of 40 hours or more per week, aged between 18 and 47 years. Among the main side effects of anxiolytic consumption were sleepiness and decreased reflexes. Conclusion: There is a need for stricter control in dispensing these drugs, as in their indications, thus preventing inappropriate consumption or the occurrence of dependence by professionals. Psychosocial support is fundamental for the rational use of these drugs and in

${ }^{*}$ Correspondence to Author:

Cléber José da Silva

Universidade Federal de Pernambuco - Depto. de Antibióticos, Recife, PE, Brasil;

How to cite this article:

Cléber José da Silva, Rosana Maria da Conceição Silva, Felipe Ravelly Alves de Souza, Samanta Sabrina dos Santos Lopes, Taciane Maria da Silva, Rêneis Paulo Lima Silva. Prevalence in the Use of Anxiolytics Among Nursing Professionals: an Integrative Review. International Journal of Psychological Research and Reviews, 2020, 3:34 improving the quality of life of health professionals.

Keywords: Prevalence and Anxiolytics, Health Professionals, Mental Health, Nursing.

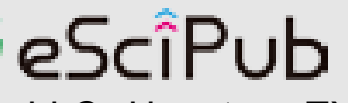

eSciPub LLC, Houston, TX USA. Website: https://escipub.com/ 


\section{INTRODUCTION}

Since the dawn of humanity, there has been widespread use of chemicals through teas, solutions and herbs that cause changes in the level of consciousness of those who use it and produce adverse physical and mental reactions, legally or illegally for the purpose of obtaining sensations associated with pleasures, euphoria or decreased symptoms related to anxiety, insomnia, depression, among other psychodepressive problems, due to the profound transformations in the economic and cultural sphere accompanied by pressures from a modern, especially increasingly competitive, social and technological society ${ }^{1}$.

In this context, the benzotiazepine class psychotropics stand out, being the most observed in medical prescriptions, since they are the drugs used as the first line of treatment for anxiety and insomnia disorders ${ }^{2}$. The first drug in this class was chlordiazepoxide, synthesized in the 1950s and still used today ${ }^{3}$. Research indicates that there is excessive and inappropriate use among individuals using benzodiazepines ${ }^{4}$.

In Brazil, one of the factors that contribute to the indiscriminate use of psychotropic drugs is the free distribution of these drugs through government programs, without greater control measures, which facilitates their acquisition. Inadequate medical prescriptions also contribute to the maintenance of chronic benzodiazepine use. Most consumers receive prescriptions from general practitioners or other medical specialties rather than psychiatrists. This reality promotes the emergence of several complications resulting from prolonged use of these drugs, such as tolerance and dependence ${ }^{5}$.

The most likely individuals to use benzodiazepines for anxiety or sleep disorders are health professionals, with prevalence between 20 and $80 \%$, because they have a fragility caused by excessive stress, excessive workload, dissatisfaction in the workplace or family ${ }^{6,7}$. Health professionals, such as doctors and nurses, are the most susceptible to the use and development of tolerance and dependence related to the use of some psychotropic substance, due to the greater possibility of selfadministration and free access to these substances in the workplace ${ }^{8}$.

The accomplishment of this research becomes relevant to reach a specific knowledge about the subject, besides promoting a better rationalization of anxiolytic consumption among health professionals, and may subsidize more effective health actions in demedicalization.

Given the above, this study aims to identify the prevalence of anxiolytic use among nursing professionals through an integrative literature review from 2013 to 2018.

\section{METHODOLOGY}

The study was an integrative bibliographic review, defined as a research developed through materials already elaborated, providing a broader view on a given subject, conducted by a research question constructed in a clear and objective $\mathrm{e}^{9,10}$.

The Integrative Review is a method widely used internationally in nursing research and evidencebased practice, as it summarizes findings from studies with different methodologies in the same review $^{11,12}$.

For the bibliographic survey, the period from April to June 2018 was used, obeying the following stages of construction: 1) delimitation of the theme and construction of the conducting question; 2) use of inclusion and exclusion criteria of studies and choice of scientific bases for electronic search; 3) identification / tracking of descriptors and data to be listed in the selected studies with their categorization; 4) interpretation of the selected studies with fluctuating reading and complete reading; 5) elaboration of the results and discussions found in the databases; and 6) synthesis of data and presentation of the knowledge produced on the verified bases.

The main question for this study was: "What is the prevalence of anxiolytic use among nursing 
professionals according to the literary publications of 2013 and 2018?" As an eligibility criterion, scientific articles published in journals between 2013 and 2018, in English and Portuguese. Incomplete scientific articles, paid for and outside the research context, were excluded.

The Virtual Health Library (VHL), Latin American and Caribbean Health Sciences Literature (LILACS) and PubMed were consulted using controlled descriptors obtained from the Health Sciences Descriptors (DeCS): "Prevalence", "Anxiolytics", "Health Professionals", "Mental Health" and "Nursing", combined by Boolean operators "AND" and / or "OR".

Initially, 400 publications were found, but after reading the respective themes, 150 were discarded. Of the 250 remaining articles from the first selection, 200 were excluded after reading the abstracts because they had one or more exclusion criteria and 20 because they were repeated in different databases. After reading the full articles, 23 were excluded because they did not directly address the issue in question. Therefore, the final sample consisted of 07 publications. After applying these criteria and selecting the articles, they were analyzed and discussed.

\section{RESULTS}

The scientific articles included in this review are in Table 1 according to the journal name, article title, author (s) and year of publication; Table 2, according to the scenario in which it was possible to conduct research and applied methodology; and Table 3, referring to the objectives and results found.

Table 01: Summary of the researched studies regarding the journal, title, author (s) and year of publication.

\begin{tabular}{|c|c|c|c|}
\hline & PERIODIC & TITLE OF ARTICLE & $\begin{array}{l}\text { AUTHOR AND } \\
\text { YEAR OF PUBLICATION }\end{array}$ \\
\hline 01 & $\begin{array}{l}\text { Revista de Enfermagem UFPE on } \\
\text { line }\end{array}$ & $\begin{array}{l}\text { Uso de medicamentos psicoativos entre } \\
\text { profissionais de saúde }\end{array}$ & Maciel et al $(2017)^{11}$ \\
\hline 02 & Arquivos de ciências da saúde & $\begin{array}{l}\text { Depressão e uso de medicamentos em } \\
\text { profissionais de enfermagem }\end{array}$ & Pereira et al $(2017)^{12}$ \\
\hline 03 & Revista Eletrônica de Enfermagem & $\begin{array}{l}\text { Ansiedade e consumo de ansiolíticos } \\
\text { entre estudantes de enfermagem de uma } \\
\text { universidade pública }\end{array}$ & Marchi et al (2013) ${ }^{1}$ \\
\hline 04 & Infarma Ciências Farmacêuticas & $\begin{array}{l}\text { Uso de fármacos psicotrópicos por } \\
\text { profissionais da saúde atuantes da área } \\
\text { hospitalar }\end{array}$ & $\begin{array}{l}\text { Schneider e Azambuja } \\
(2015)^{13}\end{array}$ \\
\hline 05 & CINERGIS & $\begin{array}{l}\text { Uso de psicotrópicos pelo enfermeiro: sua } \\
\text { relação com o trabalho }\end{array}$ & Vieira et al $(2016)^{14}$ \\
\hline 06 & Revista Enfermagem UERJ & $\begin{array}{l}\text { Estresse ocupacional e consumo de } \\
\text { ansiolíticos por trabalhadores de } \\
\text { enfermagem }\end{array}$ & Oliveira et al $(2014)^{15}$ \\
\hline 07 & Revista de Enfermagem da UFSM & $\begin{array}{l}\text { Adoecimento e uso de medicamentos } \\
\text { psicoativos entre trabalhadores de } \\
\text { enfermagem de unidades de terapia } \\
\text { intensiva }\end{array}$ & Vieira et al $(2013)^{16}$ \\
\hline
\end{tabular}


Table 02: Summary of the researched studies about the research scenario and the applied methodology.

\begin{tabular}{|c|c|c|}
\hline & RESEARCH SCENARIO & METHODOLOGY \\
\hline 01 & $\begin{array}{l}\text { Ramalho School Hospital of Portugal and General } \\
\text { Hospital of the State of Alagoas. }\end{array}$ & $\begin{array}{l}\text { Descriptive study with a quantitative approach, with a } \\
\text { sample of } 123 \text { health professionals. }\end{array}$ \\
\hline 02 & $\begin{array}{l}\text { Pronto Socorro Hospital, located in the city of Montes } \\
\text { Claros, MG. }\end{array}$ & $\begin{array}{l}\text { Cross-sectional, quantitative, descriptive study with a } \\
\text { sample of } 86 \text { nursing professionals. }\end{array}$ \\
\hline 03 & São Paulo State Public School of Nursing & $\begin{array}{l}\text { Cross-sectional and descriptive study with a quantitative } \\
\text { approach, with a sample of } 308 \text { nursing students. }\end{array}$ \\
\hline 04 & $\begin{array}{l}\text { Hospital located in the central region of Rio Grande do } \\
\text { Sul. }\end{array}$ & $\begin{array}{l}\text { Cross-sectional observational analytical study with a } \\
\text { quantitative approach, with a sample of } 106 \text { health } \\
\text { professionals. }\end{array}$ \\
\hline 05 & $\begin{array}{l}\text { Philanthropic Hospital of the city of Campo Mourão, } \\
\text { Paraná. }\end{array}$ & $\begin{array}{l}\text { Qualitative descriptive exploratory study with samples } \\
\text { from } 17 \text { nursing professionals. }\end{array}$ \\
\hline 06 & University Hospital of Rio de Janeiro. & $\begin{array}{l}\text { Quantitative and descriptive study with a sample of } 91 \\
\text { nursing professionals. }\end{array}$ \\
\hline 07 & $\begin{array}{l}\text { Pediatric, neonatal and adult ICU of a teaching } \\
\text { hospital located in Rio Grande do Sul, Brazil }\end{array}$ & $\begin{array}{l}\text { Descriptive study with a quantitative approach involving } \\
49 \text { nursing workers. }\end{array}$ \\
\hline
\end{tabular}

\section{DISCUSSION}

With changes in the lifestyle of the population, there is a growing demand for medicines that relieve symptoms such as stress and anxiety. This accentuated demand, coupled with inadequate prescriptions from unprepared professionals, contributes to the abuse of benzodiazepines (BZDs), increasing the likelihood of adverse reactions, intoxication and also dependence on these drugs ${ }^{3}$.

When choosing to use anxiolytics, it is essential to clarify to the user the duration of drug treatment, as well as to monitor the use of these drugs. Anxiolytics may cause dependence, intoxication, cognitive and behavioral changes. The use of this type of medication may be a strategy that users present to face their anguish ${ }^{2,3}$.

Excessive use of anxiolytic medications among nursing professionals is directly linked to the overload of activities, accumulation of duties and strenuous working hours, which makes it difficult to perform tasks and conditions the increase of responsibilities in the working hours ${ }^{12,6,7}$.

Nursing workers, especially females, are among the professionals who suffer the most physical and mental pressure from workplace exhaustion and, when working in public health institutions, are most vulnerable. Causing, usually depressive crises and anxiety disorders ${ }^{17}$.

Among health professionals, especially nursing professionals, it consists mainly of women. These women sought their own independence and expanded their functions in society, going beyond domestic activities, gaining space in the labor market13. However, this advance brought more responsibilities, which consequently opened a gap for the onset of anxiety disorders and other psychic disorders, which explains the high consumption of anxiolytics and other medications by nurses ${ }^{18}$. 
Cléber José da Silva et al., IJPRR, 2020 3:34

There is a prevalence of anxiolytics among married nursing professionals who work at or above 40 hours per week. The authors suggest that this prevalence is associated with work overload, which ends up compromising the family contact of health professionals, ruining the dialogue with their families. It is also assumed that psychoactive drug use is linked to the conflicts these professionals face to meet work demands and also to reconcile them with family responsibilities ${ }^{19}$.

Table 3: Summary of the researched studies regarding the objectives and results found.

\begin{tabular}{|c|c|c|}
\hline & RESEARCH OBJECTIVE & RESULTS \\
\hline 01 & $\begin{array}{l}\text { To identify psychoactive drug use } \\
\text { among } 123 \text { health professionals. }\end{array}$ & $\begin{array}{l}80.5 \% \text { were female, } 37.4 \% \text { had } 16 \text { years or more of experience in the area, } \\
14.6 \% \text { considered themselves stressed, } 13 \% \text { suffered from insomnia, } \\
9.76 \% \text { stated that psychoactive use was related to insomnia, } 37.4 \% \text { used } \\
\text { anxiolytics while working, } 63.04 \% \text { had a prescription. } 65.21 \% \text { had used } \\
\text { anxiolytics for less than a year; } 34.78 \% \text { used anxiolytics at age five. }\end{array}$ \\
\hline 02 & $\begin{array}{l}\text { To identify levels of depression and } \\
\text { medication use in nursing } \\
\text { professionals in the city of Montes } \\
\text { Claros - MG. }\end{array}$ & $\begin{array}{l}\text { Of the } 86 \text { nursing professionals, } 62.8 \% \text { were female, } 51 \% \text { were married; } \\
46.5 \% \text { worked at night, } 58.1 \% \text { had high school / technical; } 59.3 \% \text { had no } \\
\text { depression; however, } 40.7 \% \text { had depression; } 29.1 \% \text { reported using } \\
\text { anxiolytics and antidepressants; }\end{array}$ \\
\hline 03 & $\begin{array}{l}\text { To analyze the presence of anxiety } \\
\text { in nursing students at a public } \\
\text { university in the state of São Paulo; } \\
\text { to evaluate the knowledge of } \\
\text { students using anxiolytic drugs and } \\
\text { to characterize the pattern of drug } \\
\text { use. }\end{array}$ & $\begin{array}{l}\text { Of the } 308 \text { nursing students, } 85.4 \% \text { were female; } 84 \%(n=260) \text { of the } \\
\text { students never used anxiolytics; however, } 16 \%(n=48) \text { used these drugs, } \\
\text { of which } 35 \% \text { were bachelors in nursing and } 65 \% \text { graduated in nursing; } \\
35.4 \% \text { had severe anxiety according to the application of the Beck Anxiety } \\
\text { Inventory. } 37.5 \% \text { used diazepam and } 16.7 \% \text { used clonazepam; } 62 \% \text { had } \\
\text { doubts about anxiolytic interactions with other medications and } 57 \% \text { did not } \\
\text { know the side effects of anxiolytics. }\end{array}$ \\
\hline 04 & $\begin{array}{l}\text { To evaluate the use of psychiatric } \\
\text { drugs by hospital health } \\
\text { professionals. }\end{array}$ & $\begin{array}{l}\text { Of the } 106 \text { professionals, } 75.5 \% \text { worked the morning shift; } 91.5 \% \text { were } \\
\text { female; } 47.2 \% \text { were between } 18 \text { and } 29 \text { years old; } 49.1 \% \text { were married; } \\
74.5 \% \text { were nursing technicians; } 40.6 \% \text { were from the Adult Inpatient Unit } \\
\text { sector; } 56.6 \% \text { worked in the hospital for a period of } 4 \text { years or less; } 85.8 \% \\
\text { worked from } 21 \text { to } 40 \text { hours per week; } 30.4 \% \text { used antidepressants; } 17.4 \% \\
\text { used anxiolytics; } 21.7 \% \text { use the drugs for a period of } 2 \text { years or less; } 73.9 \% \\
\text { stated that the drugs used were causing side effects and } 8.7 \% \text { increased } \\
\text { the dose of the drug without prior medical consultation. }\end{array}$ \\
\hline 05 & $\begin{array}{l}\text { To identify among the nursing } \\
\text { professionals of a philanthropic } \\
\text { institution if the psychoactive } \\
\text { medication and the occurrence of } \\
\text { work overload. }\end{array}$ & $\begin{array}{l}\text { Of the } 17 \text { participants, } 16 \text { were female; } 7 \text { were formed five years ago and } 9 \\
\text { less than five years ago. Of the } 17 \text { participants, } 9 \text { had postgraduate } \\
\text { degrees; } 8 \text { worked during the day, } 4 \text { in the afternoon and } 5 \text { at night; The } \\
\text { average age was } 27.9 \text { years, ranging from } 23 \text { to } 47 \text { years; } 5 \text { professionals } \\
\text { were married, } 12 \text { were single; } 7 \text { had children; } 13 \text { reported having another } \\
\text { job; } 11 \text { claim to be responsible for more than one service unit during working } \\
\text { hours. } 70.5 \% \text { use anxiolytics, of which } 44 \% \text { self-medicate. }\end{array}$ \\
\hline 06 & $\begin{array}{l}\text { To identify the consumption of } \\
\text { anxiolytics by nursing workers and } \\
\text { correlate them with occupational } \\
\text { stress. }\end{array}$ & $\begin{array}{l}\text { Of the } 91 \text { workers }(100 \%), 72 \text { were female }(79.1 \%) ; 27 \text { were nurses } \\
(29.7 \%) ; 64 \text { were nursing technicians }(70.3 \%), 42 \text { were married }(46.1 \%) \text {, } \\
37 \text { were single }(40.7 \%) \text { and } 3 \text { were widowed }(3.3 \%) \text { aged } 25 \text { to } 64 \text { years } \\
(84.5 \%) ; 39(42.9 \%) \text { used anxiolytics throughout their lives; } 18(19.9 \%) \\
\text { used anxiolytics in the last year and } 9(9.9 \%) \text { used anxiolytics in the month } \\
\text { of data collection. According to the interviewees, the main indication for the } \\
\text { use of these medications was due to stress at work or conflicts with the } \\
\text { team. The main effects related to the use of anxiolytics were pain, } \\
\text { drowsiness and decreased reflexes. }\end{array}$ \\
\hline 07 & $\begin{array}{l}\text { To identify the disease and the use } \\
\text { of psychoactive medicines among } \\
\text { nursing workers of Intensive Care } \\
\text { Units. }\end{array}$ & $\begin{array}{l}\text { Of the } 49 \text { nursing workers, } 24.4 \% \text { reported having some mental illness, } \\
\text { among which depression is the most common, with } 14.2 \% \text {. The night shift } \\
\text { was the most significant in relation to workers diagnosed with mental } \\
\text { problems, with } 43.7 \% \text {; where } 28.5 \% \text { used anxiolytics; } 12.2 \% \text { used } \\
\text { antidepressants; } 24.4 \% \text { reported that these medications were purchased } \\
\text { on prescription and } 63.2 \% \text { reported that they used anxiolytics and } \\
\text { antidepressants on their own. }\end{array}$ \\
\hline
\end{tabular}




\section{CONCLUSION}

It is observed that there is, in fact, a prevalence of anxiolytic use by nursing professionals, and that this profile is predominantly composed of married women, who work 40 hours or more per week, aged between 18 and 47 years.

It is also possible to observe that the main side effects resulting from the use of anxiolytics by nurses are drowsiness and decreased reflexes. This is worrying because they need to be fully focused on the work environment, as they play a crucial role in patient care, such as medication administration, venous access with the use of sharp objects, device handling, among others.

Therefore, it is correct to state that the excessive use of anxiolytics by nurses is harmful for those who use it and for those who depend on the care of these professionals, in this case, the patients.

Managers need to understand early the risk factors and health promotion of working nurses, as well as the safety of patients in health facilities, in order to establish the conditions for the health maintenance of professionals in the workplace. The quality of life of each team member should be a priority in health facilities.

\section{REFERENCES}

1. Marchi KC, Bárbaro AM, Miasso Al, Tirapelli CR. Ansiedade e consumo de ansiolíticos entre estudantes de enfermagem de uma universidade pública. Rev Elet Enf [Internet]. 2013;15(3):731739.

2. Silva DSD, Tavares NVS, Alexandre ARGA, Freitas DAF, Brenda MZB, Albuquerque MCS, Neto VLM. Depressão e risco de suicídio entre profissionais de Enfermagem: revisão integrativa. Rev Esc Enferm USP. 2015.

3. Fiorelli $\mathrm{K}$, Assini $\mathrm{FL}$. A prescrição de benzodiazepínicos no Brasil: uma análise da literatura. ABCS Health Sci. 2017; 42(1):40-44.

4. Linch GFC, Guido LA, Umann J. Estresse e profissionais da saúde: produção do conhecimento no centro de ensino e pesquisas em enfermagem. Cogitare Enferm. 2013.

5. Telles Filho PCPT, Chagas AR, Pinheiro MLP, Lima AMJ, Durão AMS. Utilização de benzodiazepínicos por idosos de uma estratégia de saúde da família: implicações para enfermagem. Esc Anna Nery. 2011; 15(3): 581586.

6. Nasário M, Silva MM. O consumo excessivo de medicamentos psicotrópicos na atualidade. UNIEDU [internet]. 2016;14p. Disponível em: http://www.uniedu.sed.sc.gov.br/wpcontent/uploads/2016/02/Marcela-Nasario.pdf.

7. Teles MNA Uso de drogas pelo profissional de enfermagem: uma questão de saúde do trabalhador. 2014.

8. Rocha PR, David HMSL. Padrão de consumo de álcool e outras drogas entre profissionais de saúde: retrato de alunos de cursos lato sensu de uma instituição pública. SMAD. Rev. Eletrônica Saúde Mental Álcool Drog. 2015;11(1):41-8.

9. GIL, A. C. Métodos e técnicas de pesquisa social. São Paulo: Atlas, 2014.

10. Minayo MCS, Deslandes SF. Pesquisa Social: teoria, método e criatividade. 28. ed. Rev. atual. Petrópolis: Vozes, 2016. 108p.

11. Maciel MPGS, Santana FL, Martins CMA, Costa WT, Fernandes LS, Lima JS. Uso de medicamentos psicoativos entre profissionais de saúde. Ver Enferm UFPE on line. 2017; 11(7): 2881-7.

12. Pereira IF, Faria L, Vianna RSM, Corrêa PDS, Freitas DA, Soares, WD. Depressão e uso de medicamentos em profissionais de enfermagem. Arq Ciênc Saúde. 2017; 24(1): 70-74.

13. Schneider APH, Azambuja PG. Uso de fármacos psicotrópicos por profissionais da saúde atuantes da área hospitalar. Infarma Ciên Farm. 2015; 27(1): 14-21.

14. Vieira GCG, Brida RL, Macuch RS, Massuda EM, Preza GP. Uso de psicotrópicos pelo enfermeiro: sua relação com o trabalho. CINERGIS. 2016; 17(3): 191-195.

15. Oliveira EB, Araujo PMB, Maia MPQ, Cabral JL, Brito DM, Figueredo EP. Estresse ocupacional e consumo de ansiolíticos por trabalhadores de enfermagem. Rev Enferm UERJ. 2014; 22(5): 615-21.

16. Vieira TG, Beck CLC, Dissen CM, Camponogara S, Gobatto M, Coelho APF. Adoecimento e uso de medicamentos psicoativos entre trabalhadores de enfermagem de unidades de terapia intensiva. Rev Enferm UFSM. 2013; 3(2): 205-214.

17. Linch GFC, Guido LA, Umann J. Estresse e profissionais da saúde: produção do conhecimento no centro de ensino e pesquisas em enfermagem. Rev Cogitare Enferm. 2010; 15(3): 542-547. 
18. Silva VP, Botti NCL, Oliveira VC, Guimarães EAA. Perfil epidemiológico dos usuários de benzodiazepínicos na atenção primária à saúde, $2015 . \quad$ Disponível em: http://seer.ufsj.edu.br/index.php/recom/article/vie w/546/830.

19. Azevedo DSS, Lima ED, A AA. Fatores associados ao uso de medicamentos ansiolíticos entre bombeiros militares. Rev. Bras. Epidemiol. vol.22 São Paulo 2019 Epub Mar 21, 2019. Disponível em: http://www.scielo.br/scielo.php?script=sci_arttext \&pid=S1415-790X2019000100415.

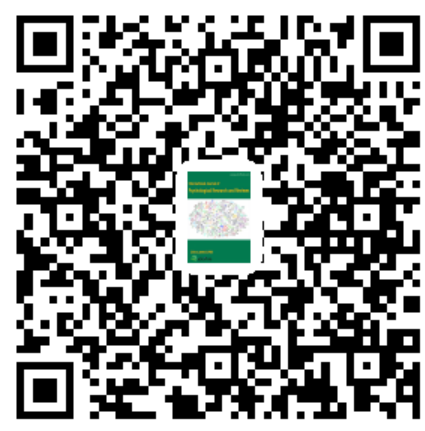

